OPEN ACCESS

Edited by: Silvio Marchini,

University of São Paulo, Brazil

Reviewed by:

Christian Gamborg,

University of Copenhagen, Denmark Jennifer Bond,

Charles Sturt University, Australia

${ }^{*}$ Correspondence:

Colin A. Simpfendorfer

colin.simpfendorfer@jcu.edu.au

Specialty section:

This article was submitted to Human-Wildlife Dynamics,

a section of the journal

Frontiers in Conservation Science

Received: 09 April 2021 Accepted: 30 June 2021 Published: 23 July 2021

Citation: Simpfendorfer CA, Heupel MR and Kendal D (2021) Complex Human-Shark Conflicts Confound

Conservation Action.

Front. Conserv. Sci. 2:692767. doi: $10.3389 /$ fcosc. 2021.692767

\section{Complex Human-Shark Conflicts Confound Conservation Action}

\author{
Colin A. Simpfendorfer ${ }^{1 *}$, Michelle R. Heupel ${ }^{2}$ and Dave Kendal ${ }^{3}$ \\ ${ }^{1}$ Centre for Sustainable Tropical Fisheries and Aquaculture, James Cook University, Townsville, QLD, Australia, ${ }^{2}$ Australian \\ Institute of Marine Science, Townsville, QLD, Australia, ${ }^{3}$ School of Geography, Planning and Spatial Sciences, University of \\ Tasmania, Hobart, TAS, Australia
}

Human-wildlife conflicts are a growing phenomenon globally as human populations expand and wildlife interactions become more commonplace. While these conflicts have been well-defined in terrestrial systems, marine forms are less well-understood. As concerns grow for the future of many shark species it is becoming clear that a key to conservation success lies in changing human behaviors in relation to sharks. However, human-shark conflicts are multidimensional, each with different ecological, social and economic implications. Sharks have functional roles as occasional predators of humans and competitors with humans for fish stocks. In addition, and unlike most terrestrial predators, sharks are also important prey species for humans, being a source of animal protein and other products taken in fisheries. These functional roles are complex and often inter-dependent which can lead to multiple kinds of conflict. Shark management for conservation and human safety is also leading to conflict between different groups of people with different values and beliefs, demonstrating that human wildlife conflict can be a proxy for human-human conflict in the marine domain. Sharks are iconic species in society, being both feared and revered. As such human beliefs, attitudes and perceptions play key roles that underpin much human-shark conflict and future work to understanding these will contribute significantly to solutions that reduce conflict and hence improve conservation outcomes.

Keywords: human-shark conflict, human-wildlife conflict, depredation, fisheries management, shark bite, shark conservation

\section{INTRODUCTION}

Human-wildlife conflicts (HWC) produce some of the most pervasive and intractable problems for the conservation of species in both terrestrial and marine domains (Dickman, 2010; Madden and McQuinn, 2015; Carter and Linnell, 2016). Conflict occurs when the behavior and needs of wildlife impact on the activities of humans, with predator attacks on humans among the most well-known of conflicts. There is also growing recognition that human-wildlife conflict can be a proxy for human-human conflict that cannot be solved through minimizing human-wildlife interactions alone (Dickman, 2010). Increasingly in conservation, the concept of conflict is being considered more broadly as a divergence of people's interests (e.g., Pruitt and Kim, 2004), and leading to HWC being recast as "conservation conflict" (e.g., Redpath et al., 2013). For example, conflict can occur over management responses, such as lethal control of "problem" wildlife (Madden, 2004), or when recovery of a threatened species has social or economic impacts on human communities (Barua et al., 2013; Redpath et al., 2013). 
There is particular fascination around human conflict with large predators, where management can be focused on both species recovery and lethal control of problem individuals that are threatening human populations or livestock (Carter and Linnell, 2016). However, there has been relatively little exploration of human-threatened predator interactions outside terrestrial environments (Gallagher, 2016).

In the marine domain, sharks (and their relatives, the rays) are involved in a range of different kinds of conflicts with humans (Figure 1). Sharks can be both predators of humans, and competitors with humans for food resources. Sharks are also important prey for humans as a source of animal protein and products for human use (Simpfendorfer and Dulvy, 2017). This diversity of conflicts arises in part because sharks are a diverse group ( $>1,200$ species) that occur in all oceans and many freshwater systems globally (Ebert et al., 2013). However, diversity in size, morphology, trophic role, habitat use, etc., mean that few individual species are involved in conflict with humans in each of these categories. Despite this, the public and many conservation actors often view sharks as a unified group, resulting in broad generalizations about their role in the ocean and their need for conservation action. Given that many shark species are threatened under international assessments of conservation status (e.g., IUCN Red List) (Dulvy et al., 2014) they require urgent conservation action, largely to address the primary threat to their existence-overfishing. Given the high level of extinction risk across the group, most conservation action is focused on minimizing species loss or promoting sustainable use. Yet the effectiveness of and support for conservation management can be undermined by human-shark conflicts, and lead to further conflict over conservation management itself (Carlson et al., 2019). For example, conflict can occur when conservation management of sharks restricts fishing, increases competition for fish resources or increases perceived threats of shark bites on humans. Conflict can also largely operate in the human domain; sharks are iconic, and threats from sharks are widely represented in the popular media (Lerberg, 2016); they are feared and revered well-beyond the experience of direct human-shark interactions. This range of relationships and the resulting range of HWCs is rarely seen in other taxonomic groups and must be recognized in the development of effective conservation policy and actions (Carlson et al., 2019). Here we consider the range of HWCs that occur with sharks and how they affect shark conservation.

\section{TYPES OF HUMAN-SHARK CONFLICT}

Human-shark conflict has arisen despite the fact that humans and sharks live in different realms. As we have expanded our use of the world's oceans humans and sharks have increasingly come in contact, at times to each other's detriment. The resulting conflicts arise from a range of human activities including extractive used of marine resources and recreation.

\section{Predation}

Animal predation on humans is a primal fear, and few species are feared more than sharks (Crossley et al., 2014). While shark bites have a very high public profile, the probability of

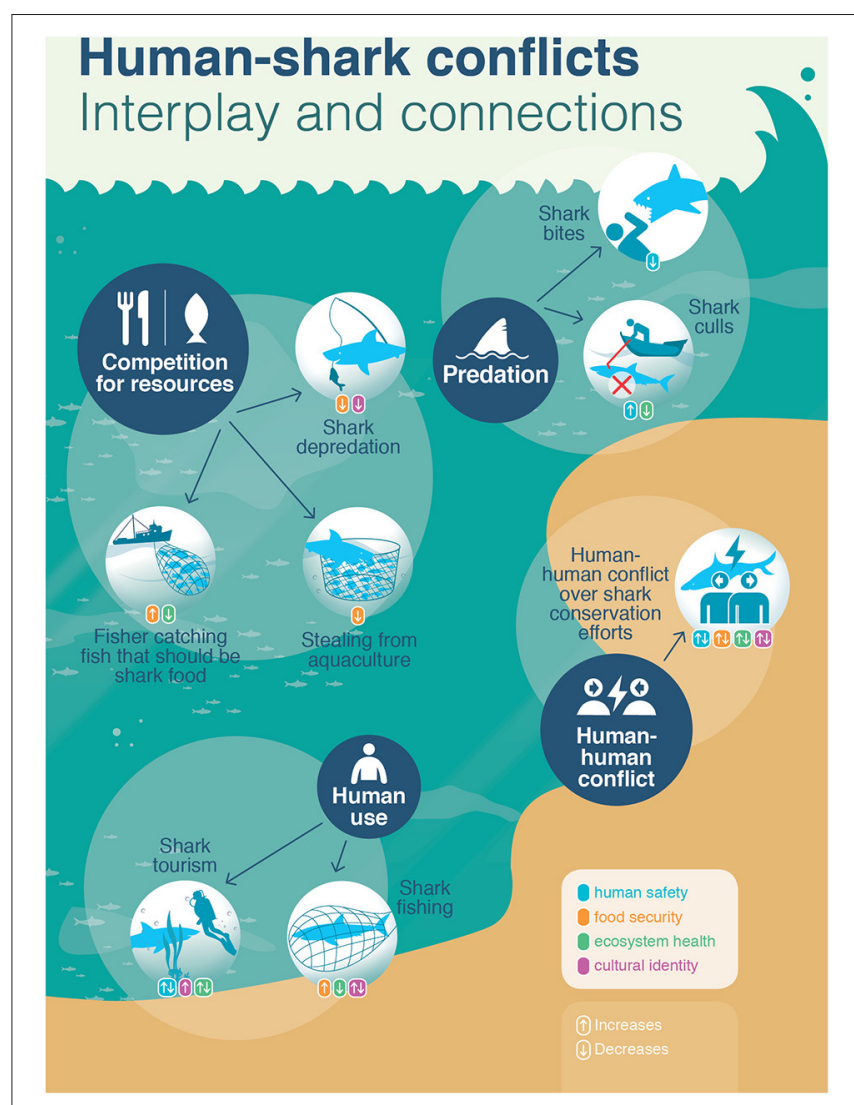

FIGURE 1 | Shark-human conflict is a multidimensional problem that is limiting the implementation of successful conservation action for sharks, and also leads to human-human conflict.

occurrence is extremely low [about 10 fatalities per year globally (McPhee, 2014)]. In the decade from 2000-2009, globally only $7 \%$ of reported unprovoked shark bites resulted in a fatality. This equates to $\sim 4.6$ fatal bites per year, a rate lower than the long-term average. Of the more than 500 species of true sharks, only three species (white, bull and tiger sharks) are responsible for over $60 \%$ of all reported shark bites and over $80 \%$ of fatal bites (West, 2011). The overwhelming majority of shark species provide very little risk to human safety. Yet public perception does not match the reality of this risk. Widespread media attention of shark bite incidents increases the perception of risk, and beach goers are more concerned about shark bites than drowning, despite the much higher likelihood of drowning (Crossley et al., 2014).

Human responses to predation include culling (eradication, regulated harvest) or exclusion (Treves and Karanth, 2003) to reduce risk of interactions. In some cases sharks are subject to directed lethal removal despite its questionable efficacy in reducing human-shark interactions (McPhee, 2014; Gibbs and Warren, 2015). These responses seek to reverse the outcome of the conflict (e.g., culls), or avoid the interactions that lead to conflict (exclusion). However, additional human-human conflict can arise when people oppose lethal management programs. 
Studies of public opinion of ocean users after a series of fatal shark bites in Australia found that a majority of people were not in favor of shark culls (Gibbs and Warren, 2015; Pepin-Neff and Wynter, 2019). Those opposed to culling believed that killing sharks did not reduced their risk of attack, that sharks play a key role in the ecosystem and that people should be aware of the risks associated with their activities. In contrast, those who supported the cull believed that shark populations were increasing and needed to be reduced. While the human-shark conflict generated by shark bites can have negative effects on the public perception of sharks and hence attitudes toward their conservation, the human-human conflict generated by the response to this conflict likely plays a negative role in pursuit of conservation outcomes.

\section{Human Use}

Sharks are commonly used as a resource by humans, and are both direct targets and incidental take of commercial, recreational, artisanal and Indigenous fisheries (Bonfil, 1994). While they have been used as a resource for centuries, over-exploitation of sharks is a modern problem created by industrialized fishing and global markets for shark products (Dulvy et al., 2017). Shark fins and meat are in particular demand, while other products including liver oil, skin, gill plates (from mobulid rays), and teeth are also used (Dent and Clarke, 2015). Sharks may also be captured and used for entertainment, education and research in public or private aquaria. Some communities are highly reliant on sharks for food or income, which has led to over-exploitation and population declines (Dulvy et al., 2014; Jaiteh et al., 2017), and conflict over sustainable use of the resource.

For this form of interaction the conflict and solution seem simple: rules are needed to manage human use of sharks (sensu Ostrom et al., 1999). However, there is no consensus on what these rules should be. Some conservation advocates believe that all shark fishing is unsustainable and should not be allowed (Shiffman and Hammerschlag, 2016); while others argue that sharks can be fished responsibly, used as a resource and contribute to food security (Simpfendorfer and Dulvy, 2017). Fishers often see shark fishing as part of their cultural heritage (e.g., Indigenous or artisanal fishers) or their right to use the species around them (e.g., recreational fishers). These conflicts reflect broader shifts in societal value orientations, away from little questioned human domination over and utilitarian use of wildlife to one where humans and wildlife can coexist (Whatmough et al., 2011; Manfredo et al., 2016).

Sharks are also used as a resource in non-consumptive ways that can lead to conflict with consumptive users. Ecotourism operators are increasingly encouraging communities to reduce or eliminate harvesting of sharks in favor of shark dive operations (Brunnschweiler, 2010; Clua et al., 2011; Cisneros-Montemayor et al., 2013). Sharks can have value simply because divers may have a chance to see them (Stoeckl et al., 2010). However, there are inherent risks in interacting with potentially dangerous species, and some disagree with purposeful human interaction with sharks and rays. It has also been suggested that shark tourism alters natural behaviors which may have negative consequences for species and create an association between people and food which increases risk to humans from shark bites
(Clua et al., 2010; Maljkovic and Cote, 2011; Brunnschweiler and Barnett, 2013).

\section{Competition for Resources}

Humans and sharks can also be in direct conflict via competition for resources. Fishing can reduce populations of prey species (e.g., DeMaster et al., 2001; Bearzi et al., 2006), likely reducing foraging success and survival of individuals and populations. There is little evidence for direct effects of prey reduction on shark populations, but it has been demonstrated for other taxa such as penguins (Robinson et al., 2015). Given the ability of humans to extract large amounts of prey species from oceans there is a high likelihood of ongoing and increased competition between sharks and humans for these vital resources.

Sharks can also deplete (or be perceived to be depleting) natural populations of species that humans use as food. For example, in Ariake Bay, Japan, concerns that ray species were depleting shellfish populations led to rays being culled to secure shellfish production (Yamaguchi, 2003). Similar to predator attacks on livestock, sharks have been reported to feed in aquaculture facilities (e.g., sea pens) housing high value species such as tuna (Papastamatiou et al., 2010). This poaching behavior by sharks is a threat to the economic viability of aquaculture businesses and can lead to culls of sharks that interact with facilities.

Depredation of catch from fishing gear, where fishers are catching fish only to have their catch consumed or damaged by sharks, is also reported increasingly (MacNeil et al., 2009; Mitchell et al., 2018). In some situations individual fishers have attacked and killed offending sharks in the hope that they can reduce the problem of depredation (Simpfendorfer unpubl. data). This behavior could have significant negative consequences for conservation if it becomes widespread. While there are currently limited data to determine the level of depredation by sharks on fishery catches, public interest in this issue is driving further investigation of the extent of this interaction.

Managing conflict over competition between sharks and humans is complex as it has multiple social and economic dimensions affecting a range of stakeholders. There is growing awareness that conservation management can itself lead to human conflict with species (Redpath et al., 2013), further complicating conservation efforts. Conservation management programs can restrict social and economic activities of local people and industries, which can cause human-human conflict where there are power and information imbalances (Redpath et al., 2013). There are often many different stakeholders with different values and objectives that shape the acceptability of management actions (Marshall et al., 2007). In the context of shark management, conservation programs can restrict or prohibit the capture and trade of sharks or shark products. These restrictions can affect humans in several ways. Reduced or prohibited catch can have social and cultural implications for groups such as recreational or Indigenous fishers who may capture these species for reasons other than economic gain. There are obvious economic implications to commercial fishers and businesses such as shark fin traders when capture or sale of 
products is reduced or prohibited. The inability to access sharks may have food security implications for coastal communities.

\section{THE VALUES OF SHARKS}

"Values" is a widely used, but complex term in conservation and natural resource management, referring to the importance of things (Ives and Kendal, 2014). Values can be seen as a person's guiding principles, such as altruism or wealth and power. Values can also be seen to occur in the environment, such as ecosystem service values. Values can be things that are important for their own sake (intrinsic values) or things that are important in achieving some other ultimate goal (instrumental values). There is much discussion in conservation about the relationships between the intrinsic worth of conserving species, and the synergies and tradeoffs with human-centered values (e.g., the social or economic well-being of people). This debate in particularly salient for sharks.

\section{Cultural Importance}

To fully understand our relationship with species their cultural significance must be considered. Sharks have played a role as iconic species for millennia. In many Pacific Island nations sharks are totemic species and play an important role in the culture of the community (e.g., Webster, 1911; Baughman, 1948; McDavitt, 2005). For example, in the Torres Strait and Hawaii, sharks have been the symbol and guide of specific clans and blood lines. Sharks have been used as religious symbols (Baughman, 1948) and are also often seen as the transporter of souls to the afterlife thus being viewed as helpful rather than fearsome. The cultural status of sharks in some areas can have synergies with conservation outcomes-they may be taboo species which are not harvested and so easy to protect. Although in other regions cultural values may adversely affect conservation outcomes, e.g., where they have been used as a source of food, trinkets, weapons and religious tokens for centuries (de Borhegyi, 1961; Drew et al., 2013).

Unlike many Indigenous cultures, western culture has often portrayed sharks as villains and man-eaters (Whatmough et al., 2011; Muter et al., 2013). They have iconic status partly based on the fear they generate in the public. Neff (2015) argues that the "Jaws effect" (from the 1975 movie) is still influencing public opinion and policy around sharks. He suggests that the movie: 1) attributes intentionality of sharks to attack humans, 2 ) introduces the concept that human-shark interactions lead to fatal outcomes, and 3) that sharks must be killed to end the threat. This framing obviously leads to poor conservation outcomes. However, western cultural attitudes to sharks have changed over time. Around the same time that Jaws was released expansion of shark fisheries was also occurring with very high catch levels throughout the 1980s (Davidson et al., 2016). At the same time, western societies views of wildlife have been shifting away from a dominionistic one to a more mutualistic one (Manfredo et al., 2016). Based on increasing concern around the status of shark populations an array of management changes have been implemented and conservation campaigns initiated (Walker, 1998; Dulvy et al., 2017). Concerted efforts to demonstrate the risks to sharks and their importance in marine ecosystems has begun to change public attitudes toward sharks. For example, the portrayal of sharks in diving publications has changed from one of feared man-eater to important ocean inhabitant (Whatmough et al., 2011). This changing view of sharks based in different value positions, could be leading to a polarization of attitudes and increasing conflict between different sectors of society. This will be a rich topic for future research to explore.

\section{Economic Importance}

The economic importance of sharks is highly variable geographically depending on the distribution of species, the value of products obtained from those species, markets for products and local reliance on species and associated products. Globally, current reported annual landings of sharks and rays are about 780,000t (Davidson et al., 2016), with the actual landing figure likely to be three to four times greater than this (Clarke et al., 2006a; Simpfendorfer and Dulvy, 2017). In many areas shark meat is traded or sold, but is typically a low value fishery product (Dent and Clarke, 2015; Martins et al., 2018). Despite this low value, harvest of sharks is a key contributor to food security in some regions, especially developing countries (Bornatowski et al., 2015; Dulvy et al., 2017). Other shark products have markets and an economic scale that goes well beyond that of shark meat alone. Many components of sharks are sold including their vertebrae for shark cartilage pills (Dent and Clarke, 2015), but the most well-known product is their fins (Clarke et al., 2006b). While the value of shark fins varies by species, fins present the greatest economic value for most fishers and drives incentive to catch or retain sharks. The demand for fins is one of the major drivers in shark fishing around the world (Clarke et al., 2007). These extractive values often lead to tension with conservation objectives and hence complicate management action.

In addition to extractive uses of sharks, some uses may have synergies with conservation. Increasingly, tourism operations are focusing on sharks providing the opportunity for new wilderness experiences with high profile charismatic species. A study on the global economic value of shark ecotourism in 2013 revealed an estimated income of US $\$ 313$ million per year (CisnerosMontemayor et al., 2013). Shark ecotourism was estimated to attract $\sim 590,000$ participants annually. This same study reported the value of shark fisheries to be $\sim$ US $\$ 630$ million, revealing the large difference in the economic value of these two industries. While there is debate over the valuations calculated for different uses of sharks (e.g., Vianna et al., 2012; Catlin et al., 2013), it is apparent that there are significant economic gains from both harvesting and watching sharks. While the economic value of the ecosystem services that sharks provide are not clear, it is no doubt significant and should be included in estimates of the economic value of sharks.

\section{Ecological Importance}

Sharks play a number of important roles in marine ecosystems. They function as top and mesopredators in coastal, reef, pelagic and deepwater habitats (Cortés, 1999; Simpfendorfer et al., 2011; Heupel et al., 2014). In these roles they have direct and indirect 
effects on ecosystems through consumption of prey and through fear effects (Wirsing et al., 2008; Ferretti et al., 2010). Given there are $>1,200$ species of sharks and rays, ranging in size from $20 \mathrm{~cm}$ to $18 \mathrm{~m}$, that occur in all of the world's oceans, the diversity of predation effects are high and cross many trophic levels (Cortés, 1999; Hussey et al., 2011). While these trophic roles are often difficult to quantify, there is little doubt that sharks function as key predators in a variety of ecosystems and that their removal can have substantial consequences for ecosystem functioning (Ferretti et al., 2010; Roff et al., 2016), including causing trophic cascades (Rasher et al., 2017). Highly mobile sharks also function as energy links between often disparate ecosystems (Heupel et al., 2015; Williams et al., 2018) meaning the consequences of even localized shark population declines may be felt over large spatial scales.

\section{SHARK CONSERVATION IN THE CONTEXT OF MULTIDIMENSIONAL CONSERVATION CONFLICTS}

The complexity of human-shark conflict has important implications for shark conservation. Shark conservation actions are often led by biologists, or based on evidence of extinction risk caused by overfishing and loss of habitat. While there is clear scientific evidence supporting the conservation (Dulvy et al., 2014) and sustainable use (Simpfendorfer and Dulvy, 2017) of sharks and rays, these do not easily accommodate the multidimensionality of shark-human conflict and the compromises that ultimately must be made to achieve conservation outcomes. A better understanding of the social, cultural and economic roles of sharks, and how these work with and against shark conservation is needed to improve the outcomes of shark conservation (Carlson et al., 2019).

Social considerations have been largely ignored in the development of shark conservation programs (MacKeracher et al., 2019). A better understanding of the social, cultural and economic implications of different conservation actions is needed for shark conservation programs that are more accepted by communities. Cultural, socio-economic and biological knowledge are all needed as an evidence base to support decisionmaking processes and policy development (Booth et al., 2019). There is increasing awareness that solutions to HWC require the human dimensions of conflict to be understood and included in management planning (Madden and McQuinn, 2015). The challenge for shark conservation is to effectively engage with stakeholders on all sides of the issue to ensure suitable outcomes, especially where livelihoods are involved.

Yet the many dimensions of human-shark conflicts that are based in different values may not be easily reconciled. In some dimensions (e.g., bites on humans, depredation) sharks may cause fear and loathing leading to negative attitudes to shark conservation, while in others (e.g., ecotourism) the conservation of sharks is strongly supported. Conservation actions may positively affect one dimension of human-shark conflict while negatively affecting another. For example, in the 1960 s and 1970s white sharks were regularly caught or culled in fisheries targeting other species. As a result, white shark populations declined globally leading to conservation intervention at national and international levels. Now, after over 20 years of protection, white shark populations are increasing in some parts of their range (Curtis et al., 2014). It is unclear whether population recovery explains an increase in the number of bites over recent years (e.g., West, 2011), but the increase has led to calls for white shark protection to be relaxed to improve human safety (Gibbs and Warren, 2015). While the evidence linking white shark recovery and human safety remains weak, the perception that white shark recovery is jeopardizing human safety remains. These concerns for human safety are often in conflict with existing conservation efforts.

Frameworks such as conservation conflict transformation have been proposed to help achieve better conservation outcomes where there is deep-seated value-base conflict (Madden and McQuinn, 2015). This distinguishes between the surface-level dispute, often the focus of conservationist thinking (e.g., conflict over culling sharks to reduce risk of shark bites). However, deeper issues such as the history of interactions between parties (conservationist vs fisher vs government) may be underpinning the surface dispute that cannot be resolved through settling the dispute alone. Even deeper issues, such as the different value positions held by stakeholders outlined above can make conflict seem intractable. Yet pathways to resolving these deep-seated conflicts have been identified. An adaptation of the conflict intervention triangle for conservation contexts (Madden and McQuinn, 2015) suggests that conflicts can be tackled with a view toward progress, rather than a view to conflicts being solved. Progress can be made by working on a "triangle" of fronts: substantive issues directly related to the surface-level dispute, process issues to increase acceptance of decisions, and relationship issues to increase trust and respect between stakeholders.

At present, shark conservation is heavily rooted in western understanding and attitudes toward sharks and rays, which in recent years has seen them become accepted as critical components of ecosystems that need to be conserved by implementation of measures such as marine protected areas, bans on fishing, limitation of trade and commerce (Shiffman and Hammerschlag, 2016). However, many of the conservation challenges for sharks and rays do not occur in western countries. Our understanding of non-western human attitudes, values and beliefs toward sharks is sorely lacking and needs to be urgently addressed to understand how to best progress conservation in many regions. If attitudes, values and beliefs are different in these communities then it is likely that western approaches to conservation will be unsuccessful, and may be actively resisted causing additional unintended conflict (Robbins et al., 2006).

\section{CONCLUSION}

HWCs underpin many of the most critical wildlife conservation challenges of our day, and the situation with sharks is 
particularly complex. Managing human-shark interactions is compounded by scientific uncertainty and competing interests, attitudes, values and beliefs. The current problems will not be solved by rational, expert driven approaches alone; conservation frameworks applied in the past will likely not be appropriate in the future-innovative methods and approaches that incorporate multiple perspectives are required (Ludwig et al., 2001; Kreuter et al., 2004; Booth et al., 2019). Issues surrounding shark management include human safety, food security, ecosystem health and cultural identity, with people staking claims on both sides of each issue. These complexities mean that there will not be solutions that eliminate conservation conflicts over sharks and their conservation. However, we must strive for progress on the different elements of the conflict to provide the best possible outcomes that recognize the widest diversity of people's values of sharks.

\section{REFERENCES}

Barua, M., Bhagwat, S. A., and Jadhav, S. (2013). The hidden dimensions of human-wildlife conflict: health impacts, opportunity and transaction costs. Biol. Conserv. 157, 309-316. doi: 10.1016/j.biocon.2012.07.014

Baughman, J. L. (1948). Sharks, sawfishes, and rays: their folklore. Am. Midl. Nat. 39, 373-381. doi: 10.2307/2421591

Bearzi, G., Politi, E., Agazzi, S., and Azzellino, A. (2006). Prey depletion caused by overfishing and the decline of marine megafauna in eastern Ionian Sea coastal waters (central Mediterranean). Biol. Conserv. 127, 373-382. doi: 10.1016/j.biocon.2005.08.017

Bonfil, R. (1994). Overview of World Elasmobranch Fisheries. FAO Fisheries Technical Paper. Vol. 341. Quebec City: FAO, 1-119.

Booth, H., Squires, D., and Milner-Gulland, E. J. (2019). The neglected complexities of shark fisheries, and priorities for holistic risk-based management. Ocean Coastal Manage. 182:104994. doi: 10.1016/j.ocecoaman.2019.104994

Bornatowski, H., Braga, R. R., Kalinowski, C., and Vitule, J. R. S. (2015). "Buying a Pig in a Poke":the problem of elasmobranch meat consumption in southern Brazil. Ethnobiol. Lett. 6, 196-202. doi: 10.14237/ebl.6.1.2015.451

Brunnschweiler, J. M. (2010). The shark reef marine reserve: a marine tourism project in Fiji involving local communities. J. Sustain. Tourism 18, 29-42. doi: 10.1080/09669580903071987

Brunnschweiler, J. M., and Barnett, A. (2013). Opportunistic visitors: long-term behavioural response of bull sharks to food provisioning in Fiji. PLoS ONE 8:e58522. doi: 10.1371/journal.pone.0058522

Carlson, J. K., Heupel, M. R., Young, C. N., Cramp, J. E., and Simpfendorfer, C. A. (2019). Are we ready for elasmobranch conservation success? Environ. Conserv. 46, 264-266. doi: 10.1017/S0376892919000225

Carter, N. H., and Linnell, J. D. C. (2016). Co-adaptation is key to coexisting with large carnivores. Trends Ecol. Evol. 31, 575-578. doi: 10.1016/j.tree.2016.05.006

Catlin, J., Hughes, M., Jones, T., Jones, R., and Campbell, R. (2013). Valuing individual animals through tourism: Science or speculation? Biol. Conserv. 157, 93-98. doi: 10.1016/j.biocon.2012.07.022

Cisneros-Montemayor, A. M., Barnes-Mauthe, M., Al-Abdulrazzak, D., Navarro-Holm, E., and Sumaila, U. R. (2013). Global economic value of shark ecotourism: implications for conservation. Oryx 47, 381-388. doi: 10.1017/S0030605312001718

Clarke, S., Milner-Gulland, E. J., and Bjørndal, T. (2007). Social, economic, and regulatory drivers of the shark fin trade. Mar. Res. Econ. 22, 305-327. doi: $10.1086 / \mathrm{mre} \cdot 22.3 .42629561$

Clarke, S. C., Magnussen, J. E., Abercrombie, D. L., McAllister, M. K., and Shivji, M. S. (2006a). Identification of shark species composition and proportion in the Hong Kong shark fin market based on molecular genetics and trade records. Conserv. Biol. 20, 201-211. doi: 10.1111/j.1523-1739.2005.00247.x

\section{DATA AVAILABILITY STATEMENT}

The original contributions presented in the study are included in the article/supplementary material, further inquiries can be directed to the corresponding author/s.

\section{AUTHOR CONTRIBUTIONS}

$\mathrm{MH}$ and CS conceived of the project. MH, CS, and DK wrote and edited the manuscript. All authors contributed to the article and approved the submitted version.

\section{ACKNOWLEDGMENTS}

The authors thank the many colleagues who have discussed this topic with them to help provide an understanding of the types, scales and complexities of this topic.

Clarke, S. C., McAllister, M. K., Milner-Gulland, E. J., Kirkwood, G. P., Michielsens, C. G. J., Agnew, D. J., et al. (2006b). Global estimates of shark catches using trade records from commercial markets. Ecol. Lett. 9, 1115-1126. doi: 10.1111/j.1461-0248.2006.00968.x

Clua, E., Buray, N., Legendre, P., Mourier, J., and Planes, S. (2010). Behavioural response of sicklefin lemon sharks Negaprion acutidens to underwater feeding for ecotourism purposes. Mar. Ecol. Prog. Ser. 414, 257-266. doi: $10.3354 /$ meps 08746

Clua, E., Buray, N., Mourier, J., and Planes, S. (2011). Business partner or simple catch? the economic value of the sicklefin lemon shark in French Polynesia. Mar.Freshw. Res. 62, 764-770. doi: 10.1071/MF10163

Cortés, E. (1999). Standardized diet compositions and trophic levels of sharks. ICES J. Mar. Sci. 56, 707-717. doi: 10.1006/jmsc.1999.0489

Crossley, R., Collins, C. M., Sutton, S. G., and Huveneers, C. (2014). Public perception and understanding of shark attack mitigation measures in Australia. Hum. Dimens. Wildl. 19, 154-165. doi: 10.1080/10871209.2014.844289

Curtis, T. H., McCandless, C. T., Carlson, J. K., Skomal, G. B., Kohler, N. E., Natanson, L. J., et al. (2014). Seasonal distribution and historic trends in abundance of white sharks, Carcharodon carcharias, in the Western North Atlantic Ocean. PLoS ONE 9:e99240. doi: 10.1371/journal.pone.0099240

Davidson, L. N. K., Krawchuk, M. A., and Dulvy, N. K. (2016). Why have global shark and ray landings declined: improved management or overfishing? Fish Fish.17, 438-458. doi: 10.1111/faf.12119

de Borhegyi, S. F. (1961). Shark teeth, stingray spines, and shark fishing in ancient Mexico and Central America. Southwest. J. Anthropol. 17, 273-296. doi: 10.1086/soutjanth.17.3.3629046

DeMaster, D. P., Fowler, C. W., Richlen, M. F., and Perry, S. L. (2001). Predation and competition: the impact of fisheries on marine-mammal populations over the next one hundred years. J. Mammal. 82, 641-651. doi: 10.1644/1545-1542(2001)082\%3C0641:PACTIO\%3E2.0.CO;2

Dent, F., and Clarke, S. C. (2015). State of the Global Market for Shark Products. FAO Fisheries and Aquaculture Technical Paper.Vol. 590. Quebec City: FAO, 1-187.

Dickman, A. J. (2010). Complexities of conflict: the importance of considering social factors for effectively resolving human-wildlife conflict. Anim. Conserv. 13, 458-466. doi: 10.1111/j.1469-1795.2010.00368.x

Drew, J., Philipp, C., and Westneat, M. W. (2013). Shark tooth weapons from the 19th century reflect shifting baselines in Central Pacific predator assemblies. PLoS ONE 8:e59855. doi: 10.1371/journal.pone.0059855

Dulvy, N. K., Fowler, S. L., Musick, J. A., Cavanagh, R. D., Kyne, P. M., Harrison, L. R., et al. (2014). Extinction risk and conservation of the world's sharks and rays. eLife 3:e00590. doi: 10.7554/eLife.00590

Dulvy, N. K., Simpfendorfer, C. A., Davidson, L. N. K., Fordham, S. V., Bräutigam, A., Sant, G., et al. (2017). Challenges and priorities in shark and ray conservation. Curr. Biol. 27, R565-R572. doi: 10.1016/j.cub.2017.04.038 
Ebert, D. A., Fowler, S. L., and Compagno, L. J. V. (2013). Sharks of the World. A Fully Illustrated Guide. Plymoth: Wild Nature Press.

Ferretti, F., Worm, B., Britten, G. L., Heithaus, M. R., and Lotze, H. K. (2010). Patterns and ecosystem consequences of shark declines in the ocean. Ecol. Lett. 13, 1055-1071. doi: 10.1111/j.1461-0248.2010.01489.x

Gallagher, A. J. (2016). Coexisting with sharks: a response to carter and linnell. Trends Ecol. Evol. 31, 817-818. doi: 10.1016/j.tree.2016.08.011

Gibbs, L., and Warren, A. (2015). Transforming shark hazard policy: Learning from ocean-users and shark encounter in Western Australia. Mar. Policy 58, 116-124. doi: 10.1016/j.marpol.2015.04.014

Heupel, M. R., Knip, D. M., Simpfendorfer, C. A., and Dulvy, N. K. (2014). Sizing up the ecological role of sharks as predators. Mar. Ecol. Prog. Ser. 495, 291-298. doi: 10.3354/meps 10597

Heupel, M. R., Simpfendorfer, C. A., Espinoza, M., Smoothey, A. F., Tobin, A., and Peddemors, V. (2015). Conservation challenges of sharks with continental scale migrations. Front. Mar. Sci. 2:12. doi: 10.3389/fmars.2015.00012

Hussey, N. E., Dudley, S. F. J., McCarthy, Ian, D., Cliff, G., and Fisk Aaron, T. (2011). Stable isotope profiles of large marine predators: viable indicators of trophic position, diet, and movement in sharks? Canad. J. Fish. Aquatic Sci. 68, 2029-2045. doi: 10.1139/f2011-115

Ives, C. D., and Kendal, D. (2014). The role of social values in the management of ecological systems. J. Environ. Manage. 144, 67-72. doi: 10.1016/j.jenvman.2014.05.013

Jaiteh, V. F., Loneragan, N. R., and Warren, C. (2017). The end of shark finning? impacts of declining catches and fin demand on coastal community livelihoods. Mar. Policy 82, 224-233. doi: 10.1016/j.marpol.2017.03.027

Kreuter, M. W., De Rosa, C., Howze, E. H., and Baldwin, G. T. (2004). Understanding wicked problems: a key to advancing environmental health promotion. Health Edu. Behav. 31, 441-454. doi: 10.1177/1090198104265597

Lerberg, M. (2016). "Jabbering jaws: reimagining representations of sharks postJaws," in Screening the Nonhuman: Representations of Animal Others in the Media, eds A.E. George \& J.L. Schatz. (Washington DC: Rowman and Littlefield), 33-46.

Ludwig, D., Mangel, M., and Haddad, B. (2001). Ecology, conservation, and public policy. Ann. Rev. Ecol. Syst. 32, 481-517. doi: 10.1146/annurev.ecolsys.32.081501.114116

MacKeracher, T., Diedrich, A., and Simpfendorfer, C. A. (2019). Sharks, rays and marine protected areas: a critical evaluation of current perspectives. Fish Fish. 20, 255-267. doi: 10.1111/faf.12337

MacNeil, M. A., Carlson, J. K., and Beerkircher, L. R. (2009). Shark depredation rates in pelagic longline fisheries: a case study from the Northwest Atlantic. ICES J. Mar. Sci. 66, 708-719. doi: 10.1093/icesjms/fsp022

Madden, F. (2004). Creating coexistence between humans and wildlife: global perspectives on local efforts to address human-wildlife conflict. Hum. Dimens. Wildl. 9, 247-257. doi: 10.1080/10871200490505675

Madden, F., and McQuinn, B. (2015). "Understanding social conflict and complexity in marine conservation," in Human-Wildlife Conflict: Complexity in the Marine Environment, eds M. Draheim, F. Madden, J. McCarthy \& C. Parsons (Oxford: Oxford University Press), 3-16. doi: 10.1093/acprof:oso/9780199687145.003.0001

Maljkovic, A., and Cote, I. M. (2011). Effects of tourism-related provisioning on the trophic signatures and movement patterns of an apex predator, the Caribbean reef shark. Biol. Conserv. 144, 859-865. doi: 10.1016/j.biocon.2010. 11.019

Manfredo, M. J., Teel, T. L., and Dietsch, A. M. (2016). Implications of human value shift and persistence for biodiversity conservation. Conserv. Biol. 30, 287-296. doi: 10.1111/cobi.12619

Marshall, K., White, R., and Fischer, A. (2007). Conflicts between humans over wildlife management: on the diversity of stakeholder attitudes and implications for conflict management. Biodivers. Conserv. 16, 3129-3146. doi: 10.1007/s10531-007-9167-5

Martins, A. P. B., Feitosa, L. M., Lessa, R. P., Almeida, Z. S., Heupel, M., Silva, W. M., et al. (2018). Analysis of the supply chain and conservation status of sharks (Elasmobranchii: Superorder Selachimorpha) based on fisher knowledge. PLoS ONE 13:e0193969. doi: 10.1371/journal.pone.0193969

McDavitt, M. T. (2005). The cultural significance of sharks and rays in Aboriginal societies across Australia's top end. Paper prepared for SeaWeek 2005. Available online at http://www.mesa.edu.au/seaweek2005/pdf_senior/is08.pdf (accessed June 14, 2021).
McPhee, D. (2014). Unprovoked shark bites: Are they becoming more prevalent? Coastal Manage. 42, 478-492. doi: 10.1080/08920753.2014.942046

Mitchell, J. D., McLean, D. L., Collin, S. P., and Langlois, T. J. (2018). Shark depredation in commercial and recreational fisheries. Rev.Fish Biol. Fish. 28, 715-748. doi: 10.1007/s11160-018-9528-z

Muter, B. A., Gore, M. L., Gledhill, K. S., Lamont, C., and Huveneers, C. (2013). Australian and U.S. news media portrayal of sharks and their conservation. Conserv. Biol. 27, 187-196. doi: 10.1111/j.1523-1739.2012.01952.x

Neff, C. (2015). The Jaws Effect: How movie narratives are used to influence policy responses to shark bites in Western Australia. Aust. J. Polit. Sci. 50, 114-127. doi: 10.1080/10361146.2014.989385

Ostrom, E., Burger, J., Field, C. B., Norgaard, R. B., and Policansky, D. (1999). Revisiting the commons: local lessons, global challenges. Science 284, 278-282. doi: $10.1126 /$ science. 284.5412 .278

Papastamatiou, Y. P., Itano, D. G., Dale, J. J., Meyer, C. G., and Holland, K. N. (2010). Site fidelity and movements of sharks associated with ocean-farming cages in Hawaii. Mar. Freshw. Res. 61, 1366-1375. doi: 10.1071/MF10056

Pepin-Neff, C., and Wynter, T. (2019). Save the sharks: reevaluating and (re)valuing feared predators. Hum. Dimens. Wildl. 24, 87-94. doi: $10.1080 / 10871209.2018 .1539887$

Pruitt, D. G., and Kim, S. H. (2004). Social Conflict: Escalation, Stalemate, and Settlement, 3rd Edn. Boston, MA: McGraw-Hill.

Rasher, D. B., Hoey, A. S., and Hay, M. E. (2017). Cascading predator effects in a Fijian coral reef ecosystem. Sci. Rep. 7:15684. doi: 10.1038/s41598-017-15679-w

Redpath, S. M., Young, J., Evely, A., Adams, W. M., Sutherland, W. J., Whitehouse, A., et al. (2013). Understanding and managing conservation conflicts. Trends Ecol. Evol. 28, 100-109. doi: 10.1016/j.tree.2012.08.021

Robbins, P., McSweeney, K., Waite, T., and Rice, J. (2006). Even conservation rules are made to be broken: implications for biodiversity. Environ. Manage. 37, 162-169. doi: 10.1007/s00267-005-0009-5

Robinson, W. M. L., Butterworth, D. S., and Plagányi, É. E. (2015). Quantifying the projected impact of the South African sardine fishery on the Robben Island penguin colony. ICES J. Mar. Sci. 72, 1822-1833. doi: 10.1093/icesjms/ fsv035

Roff, G., Doropoulos, C., Rogers, A., Bozec, Y.-M., Krueck, N. C., Aurellado, E., et al. (2016). The ecological role of sharks on coral reefs. Trends Ecol. Evol. 31, 395-407. doi: 10.1016/j.tree.2016.02.014

Shiffman, D. S., and Hammerschlag, N. (2016). Shark conservation and management policy: a review and primer for non-specialists. Anim. Conserv. 19, 401-412. doi: 10.1111/acv.12265

Simpfendorfer, C. A., and Dulvy, N. K. (2017). Bright spots of sustainable shark fishing. Curr. Biol. 27, R97-R98. doi: 10.1016/j.cub.2016.12.017

Simpfendorfer, C. A., Heupel, M. R., White, W. T., and Dulvy, N. K. (2011). The importance of research and public opinion to conservation management of sharks and rays: a synthesis. Mar. Freshw. Res. 62, 518-527. doi: 10.1071/MF11086

Stoeckl, N., Birtles, A., Farr, M., Mangott, A., Curnock, M., and Valentine, P. (2010). Live-aboard dive boats in the Great Barrier Reef: regional economic impact and the relative values of their target marine species. Tourism Econ. 16, 995-1018. doi: 10.5367/te.2010.0005

Treves, A., and Karanth, K. U. (2003). Human-carnivore conflict and perspectives on carnivore management worldwide. Conserv. Biol. 17, 1491-1499. doi: 10.1111/j.1523-1739.2003.00059.x

Vianna, G. M. S., Meekan, M. G., Pannell, D. J., Marsh, S. P., and Meeuwig, J. J. (2012). Socio-economic value and community benefits from shark-diving tourism in Palau: A sustainable use of reef shark populations. Biol. Conserv. 145, 267-277. doi: 10.1016/j.biocon.2011.11.022

Walker, T. I. (1998). Can shark resources be harvested sustainably? a question revisited with a review, of shark fisheries. Mar. Freshw. Res. 49, 553-572. doi: 10.1071/MF98017

Webster, H. (1911). Totem clans and secret associations in Australia and Melanesia. J. Royal Anthropol. Inst. Great Britain Ireland 41, 482-508. doi: $10.2307 / 2843184$

West, J. G. (2011). Changes in patterns of shark attacks in Australian waters. Marine Freshw. Res. 62, 744-754. doi: 10.1071/MF10181

Whatmough, S., Van Putten, I., and Chin, A. (2011). From hunters to nature observers: a record of 53 years of diver attitudes towards sharks and rays and marine protected areas. Mar. Freshw. Res. 62, 755-763. doi: 10.1071/ MF10142 
Williams, J. J., Papastamatiou, Y. P., Caselle, J. E., Bradley, D., and Jacoby, D. M. P. (2018). Mobile marine predators: an understudied source of nutrients to coral reefs in an unfished atoll. Proc. Royal Soc. B. Biol. Sci. 285, 1-8. doi: $10.1098 / \mathrm{rspb} .2017 .2456$

Wirsing, A. J., Heithaus, M. R., Frid, A., and Dill, L. M. (2008). Seascapes of fear: evaluating sublethal predator effects experienced and generated by marine mammals. Mar. Mammal Sci. 24, 1-15. doi: 10.1111/j.1748-7692.2007.00167.x

Yamaguchi, A. (2003). Batoid species in Ariake Bay: feeding damage on bivalves. Kaiyo Monthly 35, 241-245.

Conflict of Interest: The authors declare that the research was conducted in the absence of any commercial or financial relationships that could be construed as a potential conflict of interest.
Publisher's Note: All claims expressed in this article are solely those of the authors and do not necessarily represent those of their affiliated organizations, or those of the publisher, the editors and the reviewers. Any product that may be evaluated in this article, or claim that may be made by its manufacturer, is not guaranteed or endorsed by the publisher.

Copyright (๑) 2021 Simpfendorfer, Heupel and Kendal. This is an open-access article distributed under the terms of the Creative Commons Attribution License (CC BY).

The use, distribution or reproduction in other forums is permitted, provided the original author(s) and the copyright owner(s) are credited and that the original publication in this journal is cited, in accordance with accepted academic practice. No use, distribution or reproduction is permitted which does not comply with these terms. 